\title{
Contingency Theory, Moderating Variable and Mediating Effect in The Economic Sphere
}

Contingency theory merupakan kondisi dimana suatu perusahaan dapat mencapai kinerja yang efektif ketika struktur perusahaan berada pada titik yang signifikan sehingga mampu menangani kontingensi. Sebuah perusahaan memiliki keterkaitan yang erat dengan lingkungan, karena kebutuhan akan sumber daya guna mempertahankan keberadaannya. Teori ini memiliki maksud guna memahami bagaimana suatu perusahaan dapat menyeimbangkan antara faktor eksternal dan internal (Pratono, 2016). Ini menunjukan bahwa lingkungan eksternal tidak hanya perlu menitikberatkan fokusnya dalam sumber daya, tetapi juga perlu meningkatkan kemampuan dalam menghadapi turbulensi dari lingkungan sekitar.

Pengaruh Moderating Variable dalam sebuah model adalah memberikan dampak perubahan arah kemiringan atau koefisien variabel independent yang dapat mengurangi efek positif dari variabel independent dalam mencapai firm performance (Pratono, 2016). Dalam (Pratono, 2018), memperkenalkan turbulensi teknologi sebagai variabel moderasi dimana suatu resiko yang tinggi maka semakin tinggi pula keuntungan yang akan didapatkan. Hasil yang didapatkan antara regresi dengan variabel moderasi menunjukan bahwa pengaruh perilaku pengambilan risiko dan kinerja perusahaan, dirasa kurang memberikan dampak yang signifikan dalam teknologi informasi tinggi. Sedangkan menurut (Pratono, A.H., Ratih, R. V. S. \& Arshad, D, 2018), suatu perusahaan dihadapkan dengan berbagai ancaman berupa kendala dalam sumber daya, maka dapat melihat suatu perubahan teknologi sebagai ancaman dan dapat memberikan pengaruh yang meningkat berdasarkan turbulensi teknologi dan firm performance. Dengan demikian, turbulensi teknologi dapat memberikan efek moderasi terhadap keterkaitan tersebut. Lain halnya dengan beberapa pendapat terkait artikel diatas, menurut (Kosiba, J. P., et al, 2020), menggunakan moderating variable dalam proses menyelidiki antara ekspetasi pelanggan dan niat pembeli. Moderating variable turut ambil bagian dalam mengembangkan pemahaman terkait ekspetasi pelanggan dan menyelidiki karakteristik konsumen. Hal ini juga memberikan kontribusi penting dalam hal pengaruh pendapatan konsumen. Sedangkan dalam (Moaniba, I. M., Su, H. N., Lee, P. C., 2020) moderating variable digunakan untuk menyelidiki peran moderasi baik dari kolaborasi antar 
perusahaan hingga kolaborasi antar negara. Berdasarkan penelitian yang telah dilakukan baik secara kolaborasi antar perusahaan maupun lintas negara, diperoleh efek moderasi positif yang signifikan pada hubungan antara jarak geografis dan profitabilitas perusahaan.

Mediating Effect merupakan suatu metode statitstik yang umumnya menjelaskan proses antara variabel independent dan variabel dependent atau menjelaskan keterkaitan hubungan antara dua variabel yang berbeda (Wang, L., et al, 2020). Penerapan mediating effect biasanya digunakan dalam proses analisis interaksi antara variabel yang berbeda. Efek yang dihasilkan dari mediating effect ini adalah mengacu pada pengaruh tidak langsung antara variabel independen terhadap variabel dependen melalui pengaruh variabel mediasi (Gan, T., et al, 2020). Secara khusus, penggunaan mediating effect turut berkontribusi dalam memperdalam pemahaman hubungan antara variabel independent dan variabel dependen saat variabel ini tidak memiliki keterkaitan hubungan langsung yang jelas.

Dalam (Pratono, A.H., Darmasetiawan, N.K., Yudiarso, A. and Jeong, B.G, 2019), Mediating effect menjelaskan keterkaitan hubungan variabel mediasi yang dimana beroperasi sebagai receiving the input dari variabel independent yang turut berperann sebagai exogenous constructs dan keunggulan kompetitif perusahaann sebagai output. Dalam pengaplikasiannya, mediating effect menunjukan efek yang signifikan dalam proses mencapai firm performance. Sedangkan dalam (Pratono, A. H, 2018) Umumnya, mediating effect diaplikasikan guna mengidentifikasi keterkaitan hubungan antara social media dengan variabel mediasi. Terkait dengan hal itu, terdapat beberapa hal terkait mediating effect. Mediating effect of trust, meyakini suatu kepercayaan turut memiliki peran yang penting dalam membantu mempromosikan bentuk organisasi yang adaptif berupa membangun hubungan social media dengan mengurangi konflik yang ada. Suatu kepercayaan memiliki implikasi yang penting dalam perekonomian, dan dapat digunakan sebagai sarana perantara dalam transaksi yang terjadi dengan masyarakat.

Mediating effect of selling capability, mengacu pada seberapa jauh suatu Perusahaan dapat mengelola berbagai produk yang diproduksi kepada masyarakat. Mediating effect of pricing capability, kondisi dimana suatu perusahaan dapat menetapkan harga berdasarkan cerminan nilai pelanggan. Hal ini sangat bergantung dengan struktur jaringan yang dapat memberikan kualitas suatu informasi yang diterima. Kemampuan dalam mengadaptasi lingkungan dinamis ini memainkan peran sentral dalam penetapan harga dan mengarah pada peningkatan kinerja mereka (Hofer, K. M., Niehoff, L. M., Wuehrer, G, 2015). Partial mediation merupakan suatu kondisi dimana efek yang didapat secara langsung maupun tidak langsung, tetap berada pada posisi yang signifikan dalam mewakili mediation partial. 
Sementara full mediation dapat terjadi apabila pengaruh jaringan sosial terhadap kinerja perusahaan sepenuhnya dapat disebarkan berupa bantuan variabel lain. Dalam hal ini, mediating effect menunjukan hubungan yang signifikan dalam proses penerapannya guna mencapai firm performance.

\section{References}

Gan, T., et al. (2020). The effect of Economic Development on haze pollution (PM2.5) basedon a spatial perspective: Urbanization as a mediating variable. Journal of Cleaner Production, 266 , 2-12.

Hofer, K. M., Niehoff, L. M., Wuehrer, G. (2015). "The effects of dynamic capabilities on value-based pricing and export performance", in Zou, S., Xu, H. \& Shi, L.H. (Eds). Entrepreneurship in International Marketing (Advances in International Marketing, Volume 25), Emerald Group Publishing Limited, London.

Kosiba, J. P., et al. (2020). The moderating role of demographic variables on customer expectations in airport retail patronage intentions of travellers. Journal of Retailing and Consumer Services, 54 (2020), 3-5.

Moaniba, I. M., Su, H. N., Lee, P. C. (2020). Geographic distance between co-inventors and firm performance: Themoderating roles of interfirm and cross-country collaborations. Technological Forecasting \& Social Change, 157, 70-120.

Pratono, A. H. (2018). From social network to firm performance: The mediating effect of trust, selling capability and pricing capability. Management Research Review, 41 (6), 680-700.

Pratono, A. H. (2016). Strategic orientation and information technological turbulence: contingency perspective in SMEs. Business Process Management Journal, 22 (2).

Pratono, A. H. (2018). Does firm performance increase with risk-taking behavior under information technological turbulence? Empirical evidence from Indonesian SMEs. Journal of Risk Finance, 19 (4), 361-378.

Pratono, A.H., Darmasetiawan, N.K., Yudiarso, A. and Jeong, B.G. (2019). Achieving sustainable competitive advantage through green entrepreneurial orientation and market orientation: The role of inter-organizational learning. The Bottom Line, Vol. 32 No. 1, pp. 2-15.

Pratono, A.H., Ratih, R. V. S. \& Arshad, D. (2018). Does Entrepreneurial Autonomy Foster SME Growth Under Technological Turbulence? The Empirical Evidence from Indonesia. Journal of Technological Behaviour Science, 170-178.

Wang, L., et al. (2020). Performance shaping factors dependence assessment through moderating and mediating effect analysis. Reliability Engineering and System Safety, (202) 107304, 2-4. 
